\title{
Rain Garden Sedges Tolerate Cyclical Flooding and Drought
}

\author{
Randy S. Nelson \\ University of Minnesota Extension, Clay County, Moorhead, MN 56560
}

\author{
Esther E. McGinnis ${ }^{1,2}$ \\ Department of Plant Sciences, North Dakota State University, NDSU Dept. \\ 7670, P.O. Box 6050, Fargo, ND 58108-6050
}

\author{
Aaron L.M. Daigh ${ }^{1}$ \\ Department of Soil Science, North Dakota State University, NDSU Dept. \\ 7680, P.O. Box 6050, Fargo, ND 58108-6050
}

Additional index words. Carex annectens, Carex brevior, Carex grayi, Carex hystericina, Carex muskingumensis, Carex pensylvanica, Carex sprengelii

\begin{abstract}
Although sedges (Carex L. spp.) are commonly recommended for planting in rain gardens, little work has been carried out in evaluating the ability of sedge species to tolerate the challenging moisture fluctuations in this environment. Seven sedge species native to the north central United States, yellow fox sedge [Carex annectens (E.P. Bicknell) E.P. Bicknell], plains oval sedge [Carex brevior (Dewey) Mack. ex Lunell], gray's sedge (Carex grayi J. Carey), porcupine sedge (Carex hystericina Muhl. ex Willd.), palm sedge (Carex muskingumensis Schwein.), pennsylvania sedge (Carex pensylvanica Lam.), and sprengel's sedge (Carex sprengelii Dewey ex Spreng.), were evaluated in a greenhouse trial to determine their ability to tolerate repeated flooding and drought cycles. Treatments consisted of two flood periods ( 2 or 7 days), followed by one of three drought set points measured by volumetric water content (VWC) thresholds of 0.05 (severe drought), 0.10 (moderate drought), or $0.15 \mathrm{~m}^{3} \cdot \mathrm{m}^{-3}$ (drought onset). Each plant was subjected to a minimum of four flooding and drought cycles. For sprengel's sedge, plains oval sedge, gray's sedge, and yellow fox sedge, there was no significant difference in shoot counts between severe drought, moderate drought, and drought onset treatments. Shoot mass and root mass for all sedge species were significantly reduced under the severe drought set point. Plants subjected to the 7-day flood treatment exhibited significantly increased shoot mass compared with those in the 2-day flood treatment. Plains oval sedge showed a significantly higher shoot mass than all other species under all treatments. Visible damage ratings suggest that sprengel's sedge, plains oval sedge, gray's sedge, and yellow fox sedge could be suitable for the rain garden environment under all but the most extreme drought conditions. Results show that plains oval sedge, yellow fox sedge, and gray's sedge may be able to tolerate harsh flooding and drought cycles that can occur in rain gardens. For the remaining species, supplemental irrigation of rain gardens should be considered during drought.
\end{abstract}

More than $80 \%$ of the U.S. population lives in urban areas (U.S. Census Bureau, 2010). Residential and commercial districts may cover $20 \%$ and $85 \%$ of the land with impervious surfaces, respectively (Dietz and Clausen, 2005). Increasing the area covered by impervious surfaces decreases water infiltration and increases the amount of

\footnotetext{
Received for publication 23 May 2018. Accepted for publication 20 Aug. 2018.

This article is a portion of a thesis submitted by the first author in fulfilling the requirements of a master's degree.

We thank Radu Carcoana for providing technical assistance with laboratory equipment, Rodney Utter and Joseph Thompson for loaning equipment, and Harlene Hatterman-Valenti and Todd West for their valuable suggestions and comments during the preparation of this manuscript.

${ }^{1}$ Assistant Professor

${ }^{2}$ Corresponding author. E-mail: esther.mcginnis@ ndsu.edu.
}

stormwater runoff [U.S. Environmental Protection Agency (U.S. EPA), 1993]. Urban runoff contains sediment, soil nutrients, road salts, petroleum hydrocarbons, and heavy metals (Dietz and Clausen, 2005; U.S. EPA, 2005 ), and the resulting pollution is responsible for 36,305 impaired river km, 283,689 impaired lake ha, and 2246 impaired estuary $\mathrm{km}^{2}$ in the United States (U.S. EPA, 2009). The quality of urban runoff can be improved and the quantity greatly reduced by using a rain garden.

A rain garden is a shallow depression in the landscape, typically planted with herbaceous perennials, shrubs, or small trees, that collects stormwater from impervious surfaces such as roofs, driveways, or parking lots (Dietz, 2007; Dietz and Clausen, 2006). Rain gardens allow stormwater to infiltrate into the ground and recharge groundwater supplies (Dietz and Clausen, 2006; Shuster et al., 2007) while removing stormwater pollutants (U.S. EPA, 1999). Ponded water in a rain garden should not remain longer than $24 \mathrm{~h}$ and the soil pore space should drain within 48-96 h (Davis et al., 2009; MPCA, 2015). During periods of frequent rainfall events or in situations where the rain garden does not drain as designed, ponded water may remain for several days.

Rain garden plants depend on seasonal precipitation and will be subjected to cyclical flooding and drought. The U.S. EPA (1999) recommends using native plants tolerant of pollutants and varying amounts of soil moisture. Sedges belong to the genus Carex and are commonly recommended for rain gardens (Bannerman and Considine, 2003; Shaw and Schmidt, 2003). Sedges are herbaceous perennials with $\approx 2000$ species distributed worldwide and found in a wide range of habitats (Ball 1990; Bernard, 1990; Reznicek, 1990) such as wet meadows, pond and lake edges, dry grasslands, and mesic and dry forests (Schütz, 2000). It is estimated that 500 species occur in North America (Catling et al., 1990).

Few studies are available that evaluate the flood tolerance of sedges. Moog and Janiesch (1990) evaluated root growth of longbract sedge (Carex extensa Goodenough), remote sedge (Carex remota L.), and cypress-like sedge (Carex pseudocyperus L.) with soil moisture preferences of dry, moist, and saturated, respectively. Under flooded and anaerobic conditions, they found an increase in total biomass for remote sedge and cypress-like sedge, the two sedges that preferred moist and saturated soils, but not longbract sedge. A similar study by Visser et al. (2000) evaluated flood tolerance and aerenchyma formation of six alpine meadow sedges distributed in the meadow based on soil water content with evergreen sedge (Carex sempervirens Vill.) and rust-colored sedge (Carex ferruginea Scop.) growing in nonflooded soil, Davall's sedge (Carex davalliana $\mathrm{Sm}$.) and smooth black sedge [Carex nigra (L.) Reichard] in water-logged soil, and mud sedge (Carex limosa L.) and beaked sedge (Carex rostrate Stokes) partially submerged in water. Field-collected sedges were placed in flooded (water level at soil surface), submerged (water level $5 \mathrm{~cm}$ above soil surface), and drained (watered as needed) conditions for $150 \mathrm{~d}$. Although evergreen sedge and rustcolored sedge grow in nonflooded soil, both tolerated flooded conditions for $150 \mathrm{~d}$ with similar shoot and root dry weights when compared with the drained treatment. The authors also evaluated aerenchyma formation of the sedges by growing them in stagnant or aerated nutrient solutions. Aerenchyma increased in al species grown in oxygen-deficient conditions compared with the aerated nutrient solution (Visser et al., 2000). Aerenchyma tissue improves internal root aeration (Kozlowski, 1997).

Luo et al. (2008) evaluated flooding and drought tolerance of three Chinese wetland plants: woollyfruit sedge (Carex lasiocarpa Ehrh.), mud sedge (C. limosa L.), and narrow-leaf small reed [Deyeuxia angustifolia (Komarov) Y.L. Chang], which typically occur in water depths of 10-50, 10-30, and $0-10 \mathrm{~cm}$, respectively. Flooding tolerance 
was assessed over a 25 -d period and water depth was maintained at $50 \mathrm{~cm}$ above the soil surface. At the end of the study, survival of woollyfruit sedge, mud sedge, and narrowleaf small reed were $100 \%, 44 \%$, and $11 \%$, respectively. Drought tolerance of these three species was also assessed. Soil water content was measured daily over the 25 -d study and decreased to $0.1 \%$ by the experiment's end. The only plants surviving were narrow-leaf small reed, suggesting that plants surviving flooding may not be able to survive drought.

Sedge species such as gray's sedge, palm sedge, pennsylvania sedge, plains oval sedge, porcupine sedge, sprengel's sedge, and yellow fox sedge have been recommended for rain garden use (Bannerman and Considine, 2003; Hausken and Thompson, 2015; HHRCDC, 2017; Rodie et al., 2010; Schmidt et al., 2007; Shaw and Schmidt, 2003), but no scientific studies have been published to support these recommendations. Our objective was to determine the effect of cyclical flood and drought on the growth of these seven sedge species to determine their fitness for rain garden use.

\section{Materials and Methods}

Plant material. The seven sedge species selected for this research project were purchased from retail plant nurseries (Table 1) and are native to the north central United States (USDA-NRCS, 2015). The sedges represent all five wetland indicator categories in the National Wetland Plant List for the land indicator status ranges from obligate wetland to upland species. Stock plants were maintained for each sedge species and were propagated by crown division as needed to increase plant numbers.

Substrate. The substrate used for this study was composed of Metro Mix 902 (Sungro Horticulture, Agawam, MA) containing canadian sphagnum moss, composted bark, perlite, vermiculite, dolomite lime, and blue chip mixed 1:1 (by volume) with allpurpose sand (TCC Materials, Mendota Heights, MN) ranging in particle size from 0.015 to $0.050 \mathrm{~mm}$. The substrate was selected because of the availability from local vendors and the relatively quick free drainage of the media. This allows quick transition from flood to drought conditions and is expected to induce harsher conditions for plant performance as compared with a finer textured substrate. Because this study's objective is to evaluate rain garden sedge's tolerance of flooding and drought, the chosen substrate is purposefully skewed toward inducing the harshest of conditions.

A water retention curve (Fig. 1) was developed for the substrate using pressure cookers and pressure plates between -10 to -200 and -500 to $-1500 \mathrm{kPa}$, respectively (model 16001F and 1000; Soilmoisture Equipment Corp., Santa Barbara, CA). Screened substrate was placed into $5-\mathrm{cm}$ diameter plastic rings on the pressure cookers and plates, saturated with deionized water, Midwest region (Lichvar et al., 2014). Wet- and allowed to equilibrate until a uniform sheen was noticed on the substrate surface. After drainage from pressure cookers and plates ceased, the wet samples were weighed, dried at $105{ }^{\circ} \mathrm{C}$ for $48 \mathrm{~h}$, and reweighed at ovendry conditions to determine gravimetric water content. Water retention from -2190 to $-19,700 \mathrm{kPa}$ were determined indirectly with a WP4 dew point potentiometer (Decagon Devices, Pullman, WA) in a $20{ }^{\circ} \mathrm{C}$ constant temperature room. Gravimetric water contents were converted to VWCs by multiplying by $0.96 \mathrm{~g} \cdot \mathrm{cm}^{-3}$, the bulk density of the substrate. Bulk density was calculated by filling a container with a known volume with substrate and watering daily for $7 \mathrm{~d}$. The substrate was then removed and oven-dried at $105^{\circ} \mathrm{C}$ for $48 \mathrm{~h}$. The substrate was weighed at ovendry conditions and bulk density was determined by dividing the weight of the dry substrate by the volume of the substrate.

Particle density for the substrate (Metro Mix $902+$ sand), Metro Mix 902, and sand was $2.65,1.69$, and $2.72 \mathrm{~g} \cdot \mathrm{cm}^{-3}$, respectively. Particle density was calculated using the pycnometer method as described by Blake and Hartge (1986).

Sensor calibration. A range of water contents were established by adding 0-200 $\mathrm{mL}$ water in $50 \mathrm{~mL}$ increments to metal containers holding $600 \mathrm{~g}$ of air-dried soil. After adding water, substrate and water were mixed, and containers were covered with parafilm $\mathrm{M}^{\circledR}$ (Bemis Company Inc., Neenah, WI) and allowed to equilibrate for $2 \mathrm{~h}$. Substrate from each container was transferred into 1.07-L plastic pots, and the GS3 VWC sensor, connected to a ProCheck sensor readout storage system (Decagon Devices), was inserted into the middle of the container to obtain a VWC reading. Immediately after the reading, three subsamples from each pot were weighed, oven-dried at $105{ }^{\circ} \mathrm{C}$ for $48 \mathrm{~h}$, and reweighed at ovendry conditions to determine gravimetric water content. Volumetric water content was determined by multiplying gravimetric water content by bulk density and assuming that $1.0 \mathrm{~g}$ of water is equal to $1 \mathrm{~mL}$. The accuracy of the GS3 sensor was evaluated by plotting the VWC measured by the sensor vs. the VWC determined by gravimetric water content and bulk density. Because of the variation in VWC between the GS3 sensor and that determined by gravimetric water content and bulk density, a substrate-specific equation was developed and used to calculate realtime VWC of the substrate during the study: $\mathrm{VWC}=\left(-0.00004 \times\right.$ dielectric permitivity $\left.^{2}\right)+$ $0.0425 \times$ dielectric permittivity -0.1202 . Dielectric permittivity is defined as the measure of how susceptible a material is to being polarized in the presence of an external electric field and is highly correlated with a substrate's VWC (Dettmann and Bechtold, 2018).

Preliminary study. A preliminary study was conducted with yellow fox sedge, plains oval sedge, porcupine sedge, palm sedge, and pennsylvania sedge to determine the VWC needed to cause visual drought damage and

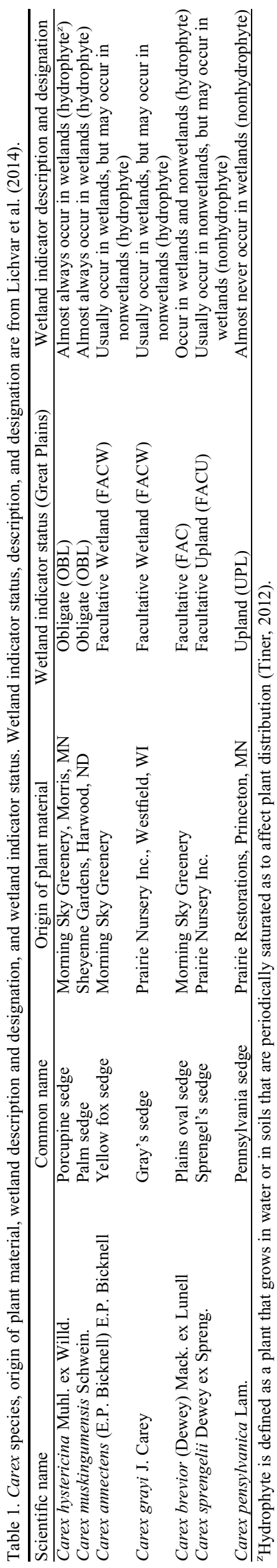




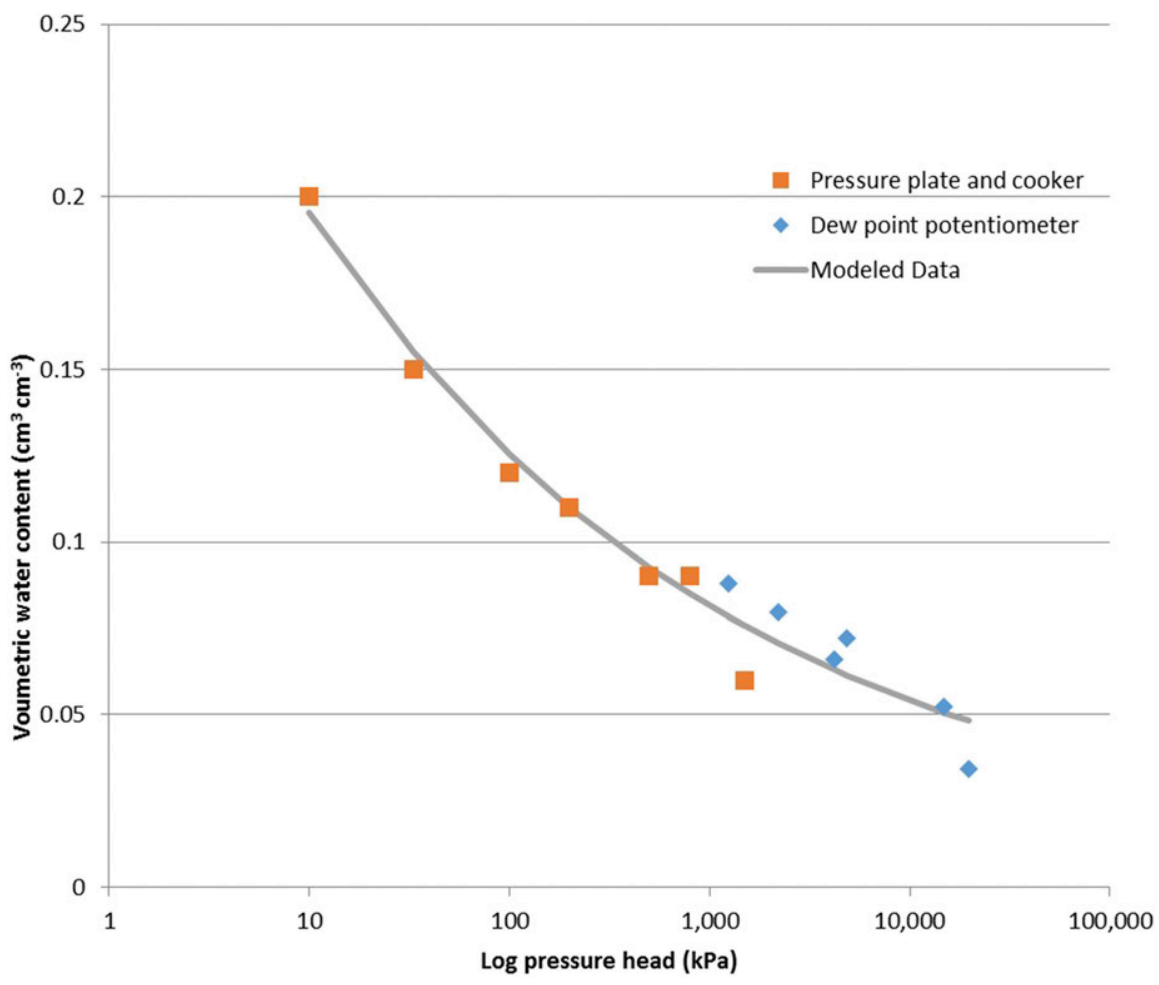

Fig. 1. Water retention curve of a 1:1 (by volume) mixture of Metro Mix 902 with all-purpose sand.

assess shoot and root growth of sedges. Sedge stock plants were divided on 1 Apr. 2015 into equal divisions for each species. Yellow fox, plains oval, and pennsylvania sedge divisions contained 30 shoots, whereas porcupine and palm sedge divisions contained 15 shoots. After dividing, shoots were cut to a height of $5.0 \mathrm{~cm}$, soil was removed from roots, and sedges were planted into $2.8-\mathrm{L}(16.5 \mathrm{~cm}$ wide $x$ $17.8 \mathrm{~cm}$ tall) nursery containers (Meyers Industries, Akron, $\mathrm{OH}$ ) filled with Metro Mix 902 and all-purpose sand as described earlier. Plants were watered as needed and fertilized weekly, with an all-purpose water-soluble fertilizer (20N-8.7P-16.6K; JR Peters Inc., Allentown, $\mathrm{PA})$ with each pot receiving $200 \mathrm{mg} \cdot \mathrm{L}^{-1}(\mathrm{~N}), 87$ $\mathrm{mg} \cdot \mathrm{L}^{-1}(\mathrm{P})$, and $166 \mathrm{mg} \cdot \mathrm{L}^{-1}(\mathrm{~K})$ until initiation of treatments on 3 July 2015. Sedges were grown under a $16-\mathrm{h}$ photoperiod in a greenhouse with supplemental lighting using 400-W high-pressure sodium lights (P.L. Light Systems, Beamsville, ON, Canada) with an output of $\approx 140 \mu \mathrm{mol} \cdot \mathrm{m}^{-2} \cdot \mathrm{s}^{-1}$ irradiance. Greenhouse set points were such that supplemental heat was provided when temperatures dropped below $18{ }^{\circ} \mathrm{C}$ and the air was cooled when temperatures reached $25^{\circ} \mathrm{C}$. Sedges were arranged in a randomized complete block design with 12 single pot replications for each of the three treatments: continual flooding, drought, or a well-watered control for $32 \mathrm{~d}$. Sedges were flooded by placing the 2.9-L container into another 2.9-L container lined with a $26.8 \times$ 27.3-cm plastic bag (SC Johnson, Racine, WI). Tap water was added until a 2-cm layer was above the substrate surface. Water was added daily to maintain this depth. Drought stress was induced on sedges by withholding water. Sedges in the well-watered control treatment were watered as needed to prevent wilting. Water frequency varied by species. Substrate VWC readings were taken every other day on sedges in the drought and well-watered treatments using a handheld GS3 VWC sensor. Sedges were rated every other day for visual plant damage using a 1 to 5 scale $(1=$ no plant damage, $2=$ start of leaf wilt, $3=$ greater than $50 \%$ of plant wilting, $4=$ onset of leaf necrosis, and $5=$ plant dead).

The results of the preliminary study suggested that visual plant damage (i.e., leaf wilt) was not occurring until the VWC was reduced to $0.10 \mathrm{~m}^{3} \cdot \mathrm{m}^{-3}$ (data not shown). There was no visual plant damage at $0.15 \mathrm{~m}^{3} \cdot \mathrm{m}^{-3}$ and severe visual plant damage (e.g., visual plant damage rating of 4 or 5) at $0.05 \mathrm{~m}^{3} \cdot \mathrm{m}^{-3}$. Based on these data, the drought set points $0.05,0.10$, and $0.15 \mathrm{~m}^{3} \cdot \mathrm{m}^{-3}$, representing severe drought, moderate drought, or drought onset, were selected for the main experiment.

Cyclical flood-drought study. Sedges were divided into equal divisions for each species. Each division of yellow fox sedge, plains oval sedge, gray's sedge, porcupine sedge, palm sedge, pennsylvania sedge, and sprengel's sedge contained 30, 30, 7, 15, 15, 30 , and 4 shoots, respectively. Sedges were allowed to establish for 3 months in a greenhouse until the start of the experiment. Greenhouse set points were described earlier. The average temperature during the study was $23{ }^{\circ} \mathrm{C}$. Treatments were initiated in 2015 on 26 Nov. (run $1,90 \mathrm{~d}$ ), and in 2016 on 20 Jan. (run 2, 78 d) and 6 Mar. (run 3, 69 d).

Treatments consisted of two flood periods, $2 \mathrm{~d}$ or $7 \mathrm{~d}$, followed by a dry-down period to one of three VWC set points as established in the preliminary study: 0.15 (drought onset), 0.10 (moderate drought), and $0.05 \mathrm{~m}^{3} \cdot \mathrm{m}^{-3}$ (severe drought) (i.e., substrate matric potentials of $-40,-300$, and $-14,800 \mathrm{kPa}$, respectively) for a total of six treatments, with each treatment having three plants. The time to reach the VWC set point varied by species and by flood duration. A well-watered control $(n=3)$ for each species was maintained for comparison. Control plants were watered as needed to keep the VWC above $0.15 \mathrm{~m}^{3} \cdot \mathrm{m}^{-3}$. Sedges were flooded for $2 \mathrm{~d}$ or $7 \mathrm{~d}$ as described in the preliminary study. The 2 -d flood represented a well-designed and functioning rain garden. The 7-d flood represented periods of frequent rain events. At the end of the 2-d or 7-d flood cycle, the outer pot with plastic bag was removed and sedges were allowed to drain. Substrate VWC readings were taken daily at the same time each day on each plant using the handheld GS3 VWC sensor. Once the substrate VWC reached the respective drought threshold of either severe drought, moderate drought, or drought onset, flooding was repeated. This cycle continued until the 7-d flood and the severe drought treatment went through four complete cycles at which point the experimental run was ended for that species. Shoot height, shoot count, and dry weight of shoots and roots were measured. A visual damage rating ( 1 to 4 scale; $1=0 \%$ to $25 \%$ dieback, $2=26 \%$ to $50 \%$ dieback, $3=$ $51 \%$ to $75 \%$ dieback, and $4=76 \%$ to $100 \%$ dieback) was assigned to each plant based on the amount of foliage necrosis. Height was measured from the soil surface to the highest living portion of leaf tissue. Shoot counts were determined by counting all living shoots that were at least $1.25 \mathrm{~cm}$ above the substrate surface. Shoots were severed at the substrate surface and roots were washed clean of substrate. Shoots and roots were placed into separate paper bags and oven-dried at $65{ }^{\circ} \mathrm{C}$ for $72 \mathrm{~h}$. After drying, shoots and roots were removed from paper bags and weighed using an electronic balance (EORW60; Ohaus Corporation, Pine Brook, NJ) to determine dry weights.

\section{Experimental Design and Statistical Analysis}

The experiment was arranged as a randomized complete block design with a $7 \times 2 \times$ 3 factorial arrangement consisting of seven species, two flood periods, and three drought set points with three single plant replications per species. The experiment was run three times. Data were pooled for analysis after determining that the variance of each was homogeneous. Before analysis, all data except visual damage ratings were expressed as percent of the control and subjected to analysis of variance (Proc MIXED, SAS 9.4; SAS Institute, Cary, NC). Experimental run was considered a random effect and species, flood, and drought as fixed effects. Treatment means were separated using TukeyKramer's honestly significant difference test. Means were considered significant at the 
$P<0.05$ level. All data except for plant height, shoot count, and visual damage rating were $\log _{10}$ transformed before analysis to standardize the variance and back-transformed for presentation of data.

\section{Results}

Relative shoot height. The main effects of species and drought set point were significant for relative shoot height. All species exhibited reduced shoot height under all treatments relative to the respective control (Fig. 2A). However, plains oval sedge and gray's sedge had less shoot height reduction than all other species. There was no difference in relative shoot height among yellow fox sedge, porcupine sedge, palm sedge, pennsylvania sedge, and sprengel's sedge. Regardless of species and flood duration, all sedges had less relative shoot height under the severe drought treatment compared with the moderate drought and drought onset treatments (Fig. 2B).

Relative shoot count. There was a significant species by drought set point interaction for shoot count. Within a sedge species, the severe drought treatment had significantly fewer shoots than the moderate drought and drought onset treatments for pennsylvania sedge, palm sedge, and porcupine sedge (Fig. 3). There was no significant difference between the moderate drought and drought onset treatments for these species. No significant difference in shoot counts existed for sprengel's sedge, plains oval sedge, gray's sedge, and yellow fox sedge plants that were exposed to the three drought set points. Plains oval sedge, gray's sedge, and yellow fox sedge receiving the severe drought treatment still had a positive relative shoot count compared with the same treatment for pennsylvania sedge, sprengel's sedge, palm sedge, and porcupine sedge, although the differences were not always significant. Only sprengel's sedge had a negative relative shoot count under all drought set points.

Relative shoot mass. The main effects of species, flood duration, and drought set point were significant for relative shoot mass. Plains oval sedge had greater relative shoot mass than all other species and sprengel's sedge had less relative shoot mass than all other sedges except porcupine sedge (Fig. 4A). Relative shoot mass for all species was increased for the 7-d flood period compared with that of the 2-d flood period (Fig. 4B). Among drought set points, sedges in the severe drought treatment produced significantly less relative shoot mass than sedges in the moderate drought and drought onset treatments (Fig. 4C).

Relative root mass. There was a species by flood duration interaction and a significant drought set point main effect for relative root mass. The species by flood duration interaction occurred in pennsylvania sedge where the 2-d flood duration treatment had significantly greater relative root mass than the 7-d flood treatment (Fig. 5A). For all other species, no significant differences existed between the 2-d and 7-d flood duration treatments. Only plains oval sedge, gray's sedge, and yellow fox sedge had positive relative root mass under both flooding treatments, but the differences were not significant. Sedges in the severe drought treatment had less relative root mass compared with those in the moderate drought and drought onset treatments (Fig. 5B).

Visual damage rating. A three-way interaction occurred for visual damage rating among species, flood duration, and drought set point. Gray's sedge in the 2-d flood duration with severe drought treatment had a high visual damage rating that exceeded 3 on the 4-point scale compared with the 2-d and 7-d flood duration with moderate drought and drought onset set points. Yellow fox sedge in the 2-d flood duration with severe drought treatment had a higher visual damage rating $(>2)$ than that in the $2-d$ flood duration with moderate drought treatment and the 7-d flood duration with drought onset treatment (Fig. 6). Both gray's sedge and yellow fox sedge had minimal damage $(\approx 1)$ under moderate and drought onset set points. For sprengel's sedge and plains oval sedge, there was no significant difference between all treatments, and the damage remained low. Pennsylvania sedge and palm sedge incurred a high level of damage (three and greater) under severe drought set points, regardless of flooding duration. Porcupine sedge had significantly greater damage under the severe drought set point $(>2)$ than that in the drought onset set point.

\section{Discussion}

Although sedges are frequently recommended for planting in rain gardens, this is the first study designed to evaluate sedge species from different wetland indicator categories under the challenging cyclical moisture
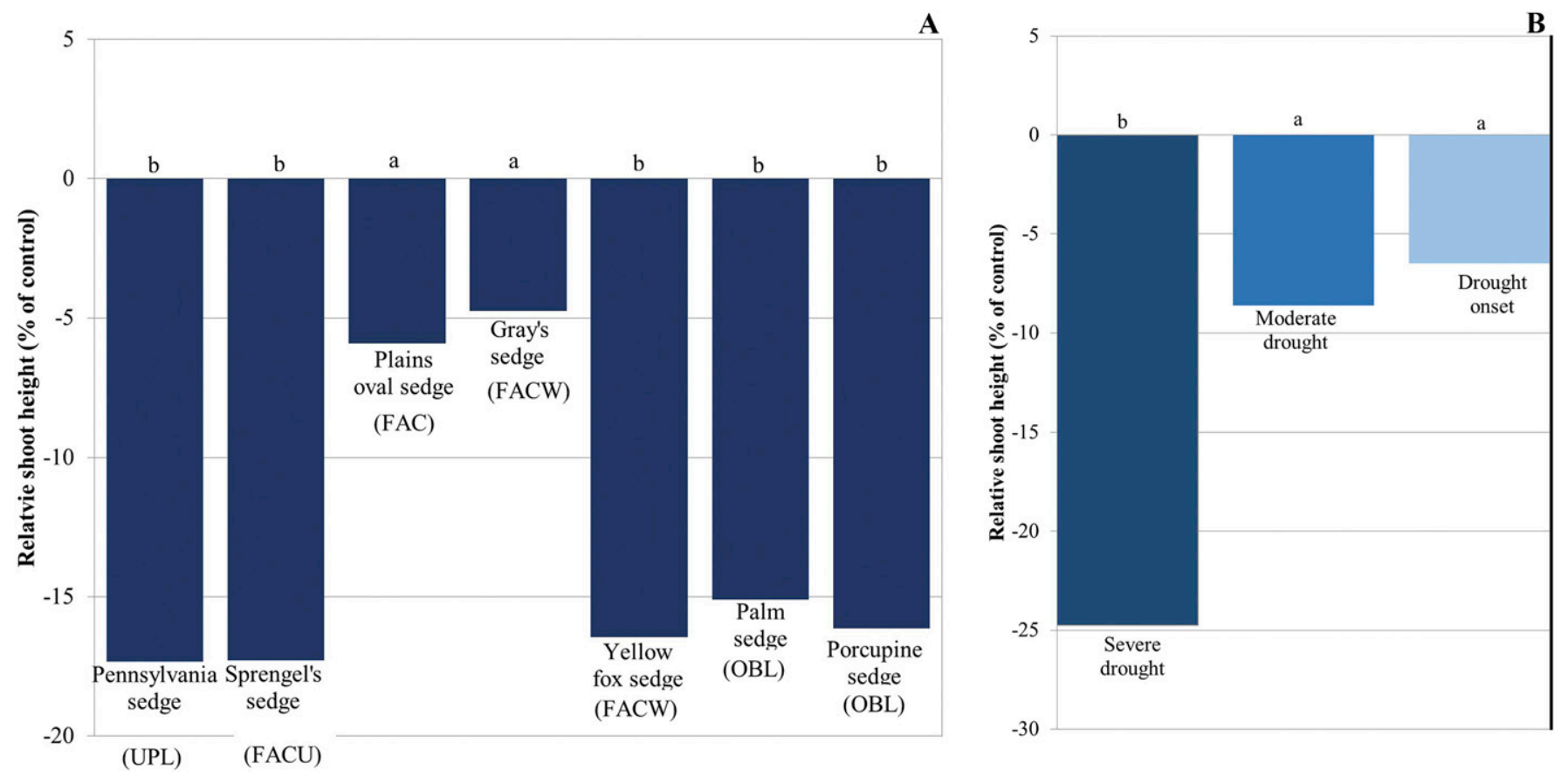

Fig. 2. Effect of cyclical flood and drought treatments on relative shoot height of sedges expressed as a percentage of the control. (A) Relative shoot height of seven sedge species. Mean values are averaged across flood and drought treatments $(n=54)$. (B) Relative shoot height for drought set points. Mean values are averaged across sedge species and flood duration $(n=126)$. Means within a figure labeled with different lowercase letters were significantly different by the Tukey-Kramer honestly significant difference test at $P<0.05$. The wetland indicator categories are as follows: OBL (obligate), FACW (facultative wetland), FAC (facultative), FACU (facultative upland), and UPL (upland). 


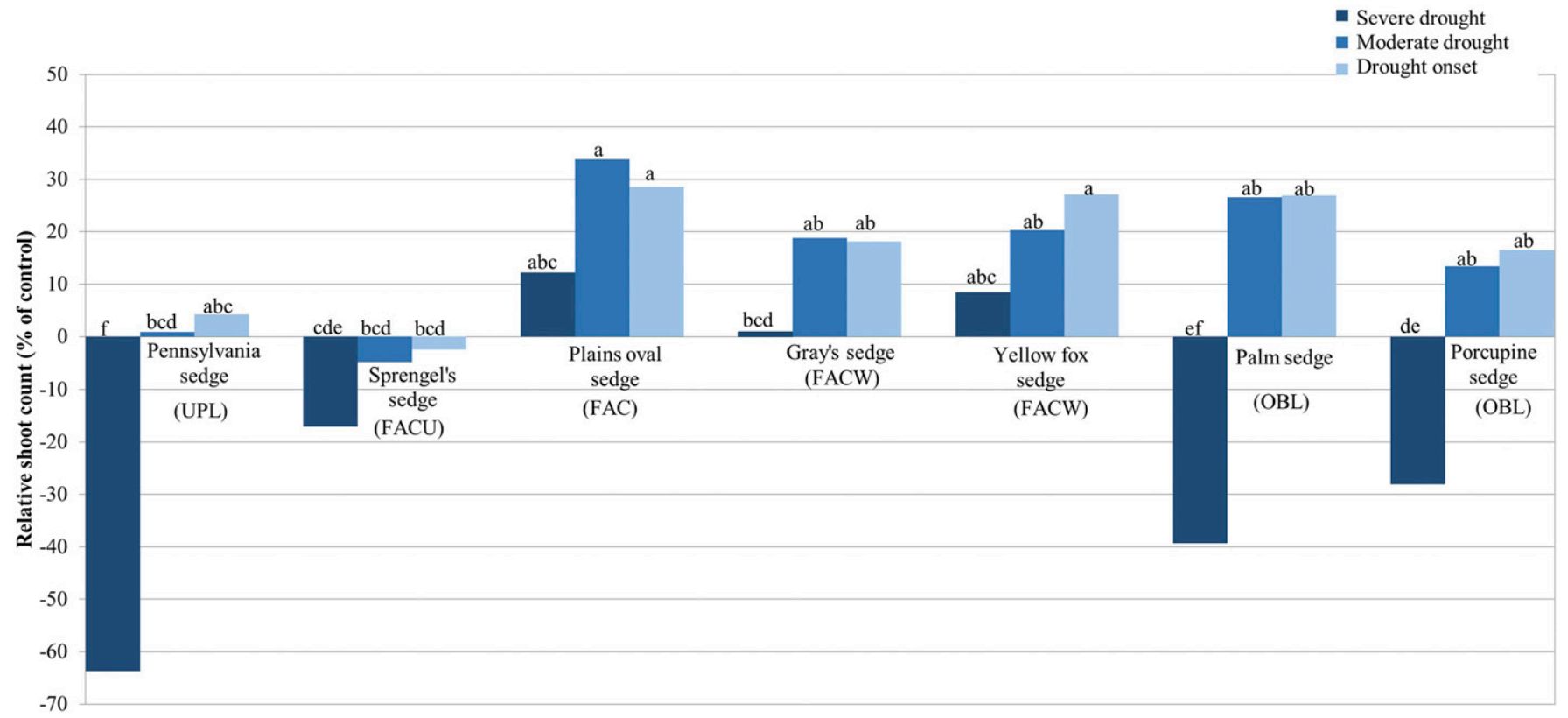

Fig. 3. Relative shoot count as a percentage of the control for seven sedge species subjected to cyclical flood and drought treatments. Mean values are averaged across flood treatments $(n=18)$. Means labeled with different lowercase letters were significantly different by the Tukey-Kramer honestly significant difference test at $P<0.05$. The wetland indicator categories are as follows: OBL (obligate), FACW (facultative wetland), FAC (facultative), FACU (facultative upland), and UPL (upland).

A

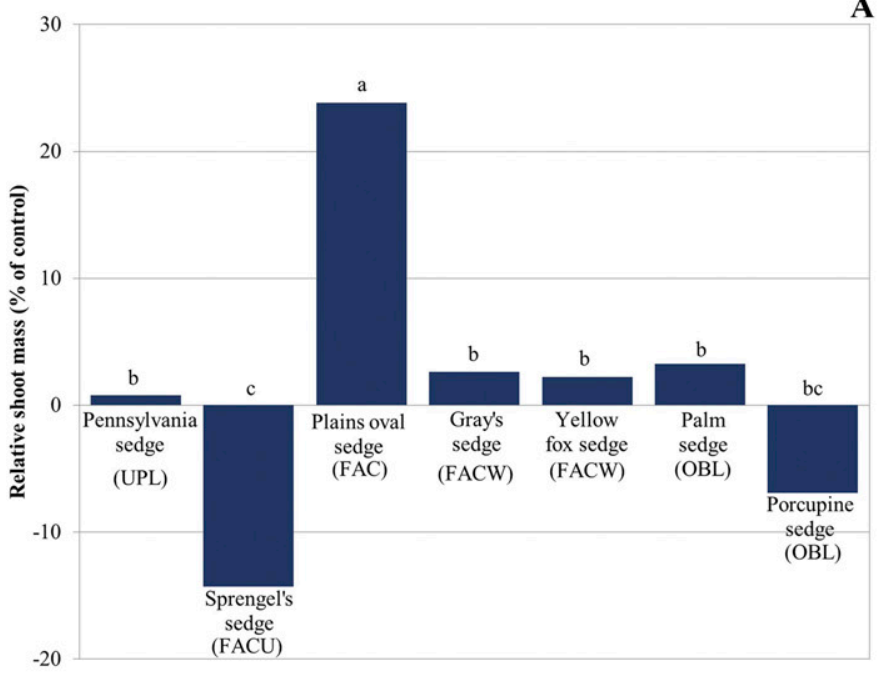

B

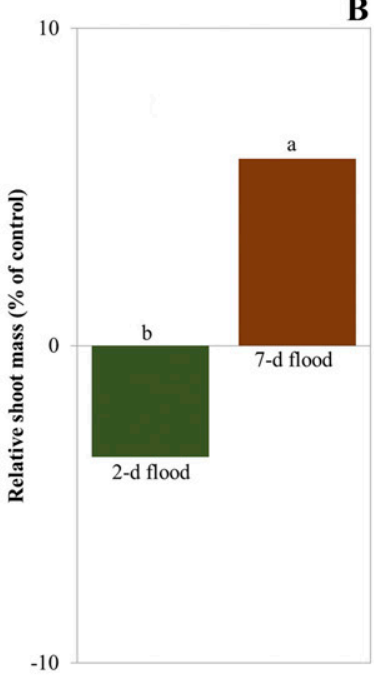

C

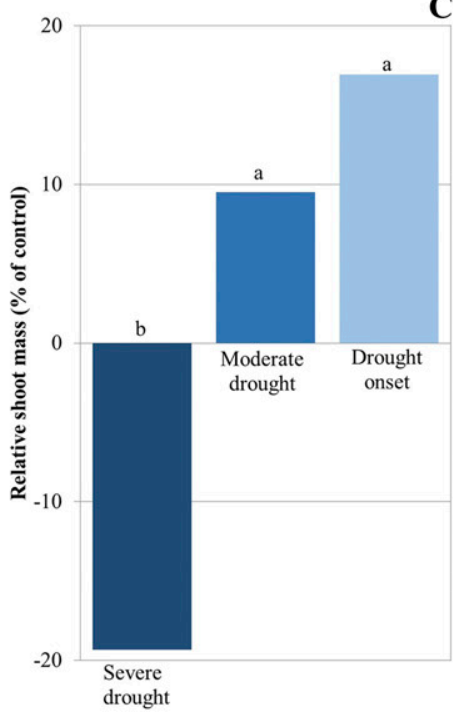

Fig. 4. Effect of cyclical flood and drought periods on relative shoot mass of sedges expressed as a percentage of the control. (A) Relative shoot mass of seven sedge species. Mean values are averaged across flood and drought treatments $(n=54)$. (B) Relative shoot mass for flood durations. Mean values are averaged across drought treatments and sedge species $(n=189)$. (C) Relative shoot mass for drought set points. Mean values are averaged across flood treatments and sedge species $(n=126)$. Means within a figure labeled with different lowercase letters were significantly different by the Tukey-Kramer honestly significant difference test at $P<0.05$. The wetland indicator categories are as follows: OBL (obligate), FACW (facultative wetland), FAC (facultative), FACU (facultative upland), and UPL (upland).

fluctuations in a rain garden. All sedges in this study were exposed to a minimum of four flooding and drought cycles. Similar studies using short-term cyclical flooding have been published by Jernigan and Wright (2011) and Dylewski et al. (2011) in woody plant species.

All sedge species exhibited a decrease in height relative to their respective controls that were maintained under optimal soil moisture conditions (Fig. 2A). This was expected, as drought stress affects plants by reducing cell division and expansion (Farooq et al., 2012). Visser et al. (2000) found that shoot height in sedges was reduced under well-drained conditions but recovered when the soil was flooded. Plains oval sedge and gray's sedge exhibited less of a height reduction than the other sedge species, thus indicating that both species were better able to handle the stress of cyclical flooding and drought. The difference in relative shoot height between facultative wetland (FACW) species, gray's sedge, and yellow fox sedge was unexpected, considering that they share a wetland indicator category. Gray's sedge had less of a reduction in shoot height than yellow fox sedge. However, this difference may be partially offset by the relative shoot count (Fig. 3). Gray's sedge produced significantly fewer shoots under the severe drought treatment than yellow fox sedge under the drought onset treatment. These two sedges 


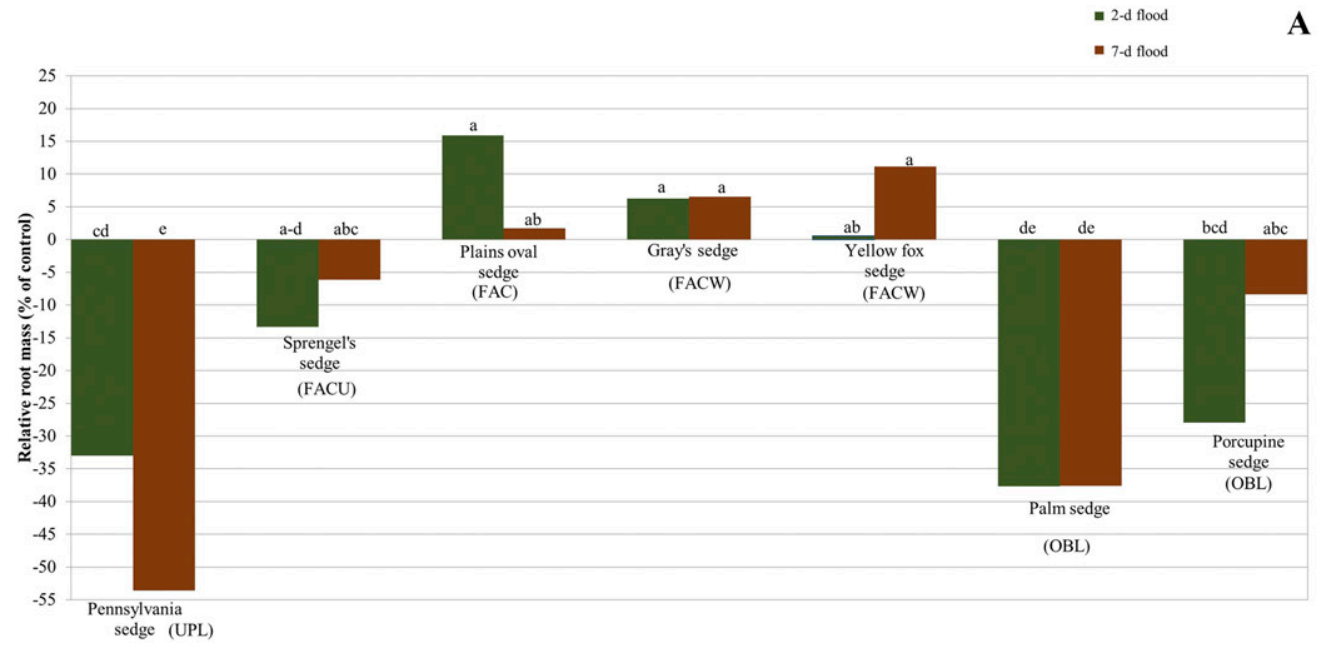

Fig. 5. Effect of cyclical flood and drought periods on relative root mass of sedges expressed as a percentage of the control. (A) Relative root mass of seven sedge species. Mean values are averaged across drought treatments $(n=27)$. (B) Relative root mass for drought set points. Mean values are averaged across flood treatments and sedge species $(n=126)$. Means within a figure labeled with different lowercase letters were significantly different by the Tukey-Kramer honestly significant difference test at $P<0.05$. The wetland indicator categories are as follows: OBL (obligate), FACW (facultative wetland), FAC (facultative), FACU (facultative upland), and UPL (upland).

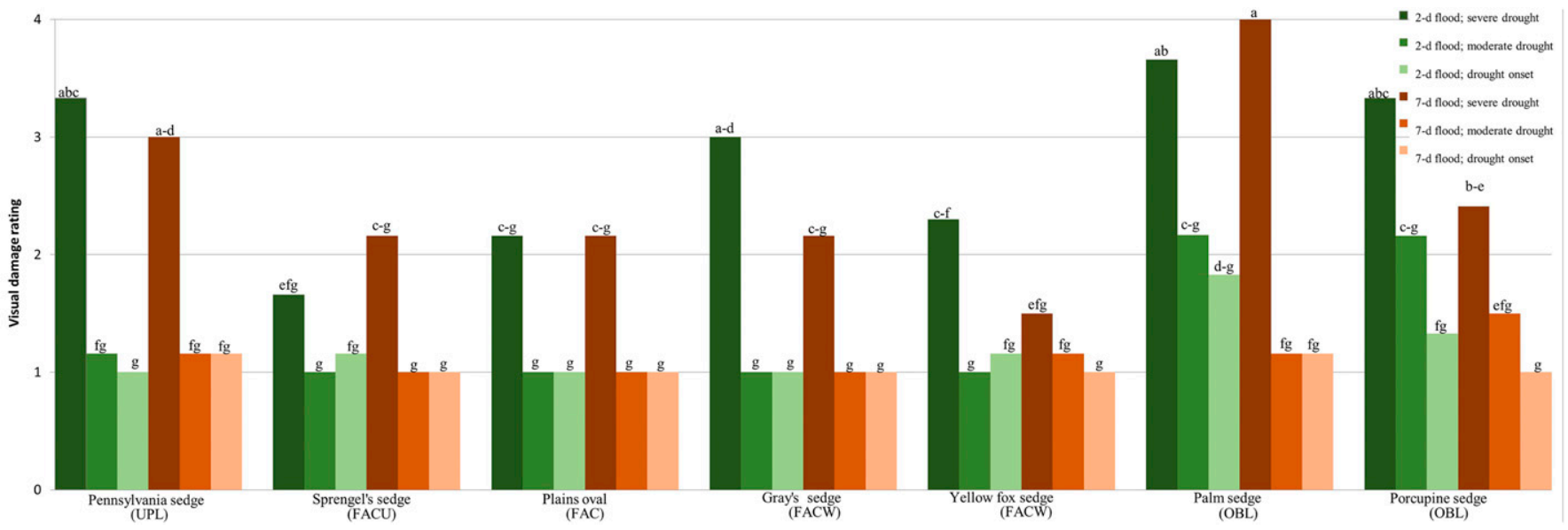

Fig. 6 . Visual damage rating ( 1 to 4 scale: $1=0 \%$ to $25 \%$ dieback, $2=26 \%$ to $50 \%$ dieback, $3=51 \%$ to $75 \%$ dieback, and $4=76 \%$ to $100 \%$ dieback) of seven sedge species subjected to cyclical flood and drought periods. Mean $(n=9)$ values labeled with different lowercase letters were significantly different by the TukeyKramer honestly significant difference test at $P<0.05$. The wetland indicator categories are as follows: OBL (obligate), FACW (facultative wetland), FAC (facultative), FACU (facultative upland), and UPL (upland).

may have different drought acclimation strategies.

Figure 2B further demonstrates the effect that severe drought had on the shoot height of all species. Under the driest VWC treatment, relative shoot height was reduced almost $25 \%$ compared with the controls. Plants grown under the two less severe drought set points showed a slight decrease in relative shoot height. This similarity may have occurred because the timeliness of inducing cyclical flooding for the drought onset set point was more difficult because of the speed in which the substrate dried from one day to the next. This often resulted in substrates reaching VWCs less than the $0.15 \mathrm{~m}^{3} \cdot \mathrm{m}^{-3}$ set point before flooding could be induced.

Severe drought adversely affected relative shoot count for pennsylvania sedge, palm sedge, and porcupine sedge (Fig. 3). Sprengel's sedge tolerated severe drought and did not exhibit significant differences in shoot count between the drought set points. Of note, plains oval sedge, gray's sedge, yellow fox sedge, palm sedge, and porcupine sedge produced $13 \%$ to $34 \%$ more shoots on average than the well-watered control under the moderate drought and drought onset treatments. Furthermore, plains oval sedge, gray's sedge, and yellow fox sedge tolerated the severe drought treatment and continued to produce a positive relative shoot count (Fig. 3).

These results may be partially explained by the wetland indicator categories. Plains oval sedge is a facultative (FAC) plant, whereas gray's sedge and yellow fox sedge are FACW plants. These are wetland indicator categories that denote plants that usually occur in wetlands but also may occur in nonwetland areas (Lichvar et al., 2014). These two wetland indicator categories are intermediate or transition categories. By con- trast, pennsylvania sedge is an upland (UPL) plant and palm sedge and porcupine sedge are obligate (OBL) wetland plants. Plants in the UPL indicator category are almost never found in wetlands, whereas plants in the OBL indicator category are almost always found in wetlands. Sprengel's sedge is a facultative upland (FACU) plant and usually occurs in nonwetlands but may occasionally be reported in a wetland habitat (Lichvar et al., 2014). Of these categories, FAC, FACW, and OBL are hydrophytes; these are plants that either grow in water or in soils that are periodically saturated as to affect plant distribution (Tiner, 2012). As hydrophytes, plains oval sedge, gray's sedge, yellow fox sedge, palm sedge, and porcupine sedge were able to produce more shoots than the wellwatered control under moderate drought and drought onset treatments because they were able to respond to more water availability 
under the 2-d and 7-d flooding treatments. Wetland sedge species have been shown to produce more biomass under flooded conditions (Visser et al., 2000). The ability to grow in transition areas may explain the versatility of plains oval sedge, gray's sedge, and yellow fox sedge, and why they were less affected by the severe drought treatment.

Relative shoot mass was positive compared with the controls for all sedge species except for sprengel's sedge and porcupine sedge (Fig. 4A). Plains oval sedge had greater relative shoot mass than all other sedge species. As its FAC designation indicates, plains oval sedge thrives under cyclical soil moisture conditions that are typically considered stressful. Regardless of species and drought set point, relative shoot mass was increased when sedges were flooded for $7 \mathrm{~d}$ compared with only 2 d (Fig. 4B). Some sedge species under flooded conditions produce more shoot biomass to absorb oxygen to compensate for oxygen-deprived soils (Luo et al., 2008; Visser et al., 2000). Comparable results were found by Moog and Janiesch (1990) where two of the three sedge species had increased shoot mass after $40 \mathrm{~d}$ of anaerobic growth compared with the aerobic control. Similar to relative plant height, relative shoot mass was reduced for plants subjected to the severe drought treatment compared with plants subjected to drought onset or moderate drought (Fig. 4C). This finding is consistent with Luo et al. (2008).

Relative root mass was significantly decreased under both flood durations in pennsylvania sedge and palm sedge when compared with plains oval sedge, gray's sedge, and yellow fox sedge (Fig. 5A). These results were somewhat unexpected. Soil flooding has been shown to not adversely affect root biomass accumulation in six sedge species from different soil moisture environments when compared with a well-drained control (Visser et al., 2000). Visser et al. (2000) had hypothesized that sedges from both dry and wetland environments could tolerate saturated soils because of the production of aerenchyma cells in the roots. Read et al. (2008) did not find any evidence of flood stress in tall sedge (Carex appressa $\mathrm{R}$. Br.) using fluorescence as a means of quantifying photosynthesis.

The relative root mass results in the present study are consistent with those in the wetland indicator categories. Pennsylvania sedge was the only species that had significantly less relative root mass for the 7-d flood duration compared with the 2-d flood duration. Pennsylvania sedge is an UPL sedge species and, therefore, would be expected to decline under prolonged flood conditions. Similar results were found by Moog and Janiesch (1990) for longbract sedge (authors reported that longbract sedge commonly grows in dry and sandy soils near the coastline), where $40 \mathrm{~d}$ of anaerobic growth reduced root weight compared with the aerobic control. The reduction in relative root mass for palm sedge, an OBL species, could be due to the effect of drought. The low root mass for palm sedge was somewhat unexpected for several reasons. Palm sedge is frequently recommended for rain gardens (Rodie et al., 2010). This sedge has been noted for its vigorous growth in a landscape in comparison with other ornamental grasses and sedges (Davidson and Gobin, 1998). As an OBL species, it is expected that it would cope well with flooding by producing aerenchyma tissue in the roots. However, palm sedge under severe drought stress may have lacked the capacity to resume root growth when water became available. Plants may have different capacities to recover from drought stress when subsequently exposed to flooding (Sigmon et al., 2013). Porcupine sedge, another OBL species, exhibited a similar result under the 2-d flood but not the 7-d flood.

Similar to relative shoot mass, relative root mass for all species was reduced under severe drought stress (Fig. 5B). However, no significant difference occurred between moderate drought and drought onset.

In general, larger shoot and root biomass under both cyclical drought and flooding may be a potential indicator of success in rain garden environments from another aspect. Plants with more biomass tend to remove more stormwater pollutants such as nitrogen and phosphorus (Turk et al., 2017). Other sedge species such as tall sedge have already been shown to be effective in taking up nitrogen and phosphorus from saturated soils (Brateries et al., 2008).

The visual damage rating was minor $(\approx 1)$ among all sedge species at the moderate drought and drought onset set points regardless of flood duration with the exception of palm sedge and porcupine sedge (Fig. 6). These two OBL wetland species are less tolerant of drought. Overall, sedges appear adaptable. The severe drought treatment $\left(0.05 \mathrm{~m}^{3} \cdot \mathrm{m}^{-3}\right)$ was extreme and would result in an unacceptable visual damage rating for all sedge species. Therefore, irrigation during times of drought may be necessary to keep visual damage at an acceptable level at least for home rain gardens or smaller bioretention ponds.

Overall, the wetland transition species seemed to tolerate cyclical flooding and drought better than the UPL and OBL species. Sedge species with the FAC and FACW categories performed better throughout the study. Other species within these transition wetland indicator categories may potentially be future candidates for rain garden use. However, more studies are needed to see if these trends hold true for sedges and other species.

\section{Conclusion}

Based on the results of this study, plains oval sedge, gray's sedge, and yellow fox sedge respond well to challenging moisture conditions. These transition species can potentially survive repeated flooding and drought and still have an acceptable visual damage rating in the rain garden landscape under all but the most extreme drought conditions. Of the three species, plains oval sedge has a remarkable ability to continue growing under the toughest of conditions. Like plains oval sedge, gray's sedge is adaptable and had less of a shoot height reduction when exposed to drought. Yellow fox sedge also appears to be a good rain garden candidate. Sprengel's sedge (FACU) may be a little less tolerant of stress as manifested by its significantly reduced shoot mass. The OBL wetland species, palm sedge and porcupine sedge, may be suitable for rain gardens in wetter climates or may greatly benefit from irrigation during times of drought. Surprisingly, pennsylvania sedge, an upland species, survived the study and could potentially be used in rain gardens that do not experience flooding and drought extremes. Based on this study, sedges could be well suited to moisture fluctuations in rain garden environments. All sedges discussed in this article are hardy to the north central United States, provided that the plant material is purchased from northern sources. The biggest challenge to adopting sedges for rain garden use will be retail availability. However, native plant nurseries have proliferated and are a good source for sedges.

\section{Literature Cited}

Ball, P.W. 1990. Some aspects of the phytogeography of Carex. Can. J. Bot. 68:1462-1472.

Bannerman, R. and E. Considine. 2003. Rain gardens: A how-to manual for homeowners. Univ. Wisc. Ext. Coop. Publ. GWQ037.

Bernard, J.M. 1990. Life history and vegetative reproduction in Carex. Can. J. Bot. 68:14411448

Blake, G.R. and K.H. Hartge. 1986. Particle density, p. 377-382. In: A. Klute (ed.). Methods of soil analysis: Part 1-physical and mineralogical methods. SSSA, ASA, Madison, WI

Brateries, K., T.D. Fletcher, A. Delectic, and Y. Zinger. 2008. Nutrient and sediment removal by stormwater biofilters: A large-scale design optimization study. Water Res. 42(14):3930 3940.

Catling, P.M., A.A. Reznicek, and W.J. Crins 1990. Introduction (special issue) systematics and ecology of the genus Carex (Cyperaceae) Can. J. Bot. 68:1405-140-8

Davidson, C.G. and S.M. Gobin. 1998. Evaluation of ornamental grasses for the northern great plains. J. Environ. Hort. 16(4):218-229.

Davis, A.P., W.F. Hunt, R.G. Traver, and M. Clar. 2009. Bioretention technology: Overview of current practice and future needs. J. Environ. Eng. 135:109-117.

Dettmann, U. and M. Bechtold. 2018. Evaluating commercial moisture probes in reference solutions covering mineral to peat soil conditions. Vadose Zone J. 17:170208

Dietz, M.E. 2007. Low impact development practices: A review of current research and recommendations for future directions. Water Air Soil Pollut. 186:351-363.

Dietz, M.E. and J.C. Clausen. 2005. A field evaluation of rain garden flow and pollutant treatment. Water Air Soil Pollut. 167:123-138.

Dietz, M.E. and J.C. Clausen. 2006. Saturation to improve pollutant retention in a rain garden. Environ. Sci. Technol. 40:1335-1340. 
Dylewski, K.L., A.N. Wright, K.M. Tilt, and C. LeBleu. 2011. Effects of short interval cyclic flooding on growth and survival of three native shrubs. HortTechnology 21:461-465.

Farooq, M., M. Hussain, A. Wahid, and K.H.M. Siddique. 2012. Drought stress in plants: An overview, p. 1-36. In: R. Aroca (ed.). Plant responses to drought stress from morphological to molecular features. Springer, New York, NY.

Hausken, S. and G. Thompson. 2015. Rain garden plants. 21 Apr. 2015. < http://www.extension.umn. edu/garden/yard-garden/landscaping/best-plantsfor-tough-sites/docs/08464-rain-garden.pdf $>$.

Hooiser Heartland Resource Conservation and Development Council (HHRCDC). 2017. Build your own rain garden: Plant selection and planting schemes. 1 May 2017. <http://hhred. org/pdf/Rain\%20Garden-FS-plants-final.pdf $>$.

Jernigan, K.J. and A.N. Wright. 2011. Effect of repeated short interval flooding events on root and shoot growth of four landscape shrub taxa. J. Environ. Hort. 29:220-222.

Kozlowski, T.T. 1997. Responses of woody plants to flooding and salinity. Tree Physiol. Monogr. No. 1, p. 1-29.

Lichvar, R.W., M. Butterwick, N.C. Melvin, and W.N. Kirchner. 2014. The national wetland plant list: 2014 update of wetland ratings. Pytoneuron 41:1-42.

Luo, W., F. Song, and Y. Xie. 2008. Trade-off between tolerance to drought and tolerance to flooding in three wetland plants. Wetlands 28:866-873.

Minnesota Pollution Control Agency (MPCA). 2015. Minnesota storm water manual. MPCA. 21 Apr. 2015. <http://stormwater.pca.state.mn. us/index.php/Main_Page $>$.

Moog, P.R. and P. Janiesch. 1990. Root growth and morphology of Carex species as influenced by oxygen deficiency. Funct. Ecol. 4:201-208.

Read, J., T. Wevill, T. Fletcher, and A. Deletic. 2008. Variation in plant species in pollutant removal from stormwater in biofiltration systems. Water Res. 42:893-902.

Reznicek, A.A. 1990. Evolution in sedges (Carex, Cyperaceae). Can. J. Bot. 68:1409-1432.

Rodie, S., T. Hartsig, and A. Szatko. 2010. Sustainable landscapes: Rain gardens, bioswales, and xeric gardens: Managing rain water in your yard: A manual for homeowners and small properties. City of Omaha, NE. 24 June 2017. <http:// omahastormwater.org/download/227/manuals/ id:5p9DrKDnFmAAAAAAAAACDQ/Sustainable \%20Landscapes\%20Manual $>$.

Schmidt, R., D.B. Schaw, and D. Dodds. 2007. The blue thumb guide to rain gardens: Design and installation for homeowners in the upper midwest: A guide for planting zonse 3, 4, and 5 . Waterdrop Innovations, River Falls, WI.

Schütz, W. 2000. Ecology of seed dormancy and germination in sedges (Carex). Perspect. Plant Ecol. Evol. Syst. 3:67-89.

Shaw, D. and R. Schmidt. 2003. Plants for stormwater design: Species selection for the Upper Midwest. Minnesota Pollution Control Agency. 4 Oct. 2018. <http://www.pca.state.mn.us/water/ plants-stormwater-design $>$.

Shuster, W.D., R. Gehring, and J. Gerken. 2007. Prospects for enhanced groundwater recharge via infiltration of urban storm water runoff: A case study. J. Soil Water Conserv. 62:129-137.

Sigmon, L., S. Hoopes, M. Booker, C. Waters, K. Salpeter, and B. Touchette. 2013. Breaking dormancy during flood and drought: Sublethal growth and physiological responses of three emergent wetland herbs used in bioretention basins. Wetlands Ecol. Mgt. 21:45-54.
Tiner, R.W. 2012. Defining hydrophytes for wetland identification and delineation. ERDC/ CRREL CR-12-1. U.S. Army Corps of Engineers, Washington, D.C.

Turk, R.P., H.T. Kraus, W.F. Hunt, N.B. Carmen, and T.E. Bilderback. 2017. Nutrient sequestration by vegetation in bioretention cells receiving high nutrient loads. J. Environ. Eng. 143(2):06016009.

U.S. Census Bureau. 2010. Census data 2010. U.S. Census Bureau. 10 Dec. 2014. <http://www. census.gov/2010census/data/>.

U.S. Department of Agriculture, Natural Resource Conservation Service. 2015. The plants database. National Plant Data Team, Greensboro, NC 27401-4901. 21 Apr. 2015. <http://plants. usda.gov>.

U.S. EPA. 1993. Handbook of urban runoff pollution prevention and control planning. EPA625-R-93/004. U.S. Environmental Protection Agency, Cincinnati, OH.

U.S. EPA. 1999. Storm water technology fact sheet: Bioretention. EPA-832-F-99-012. U.S. Environmental Protection Agency, Washington, D.C.

U.S. EPA. 2005. National management measures to control nonpoint source pollution from urban areas. EPA-841-B-05-004. U.S. Environmental Protection Agency, Washington, D.C., 20460.

U.S. EPA. 2009. National water quality inventory: Report to congress 2004 reporting cycle. EPA841-R-08-001. U.S. Environmental Protection Agency, Washington, D.C., 20460.

Visser, E.T.W., G.M. Bogemann, H.M. Van de Steeg, R. Pierik, and C.W.P.M. Blom. 2000 Flood tolerance of Carex species in relation to field distribution and aerenchyma formation. New Phytol. 148:93-103. 